\title{
Ethnicity and grandparental child care in the United Kingdom
}

\author{
Valeria Bordone ${ }^{1 \star}$, Maria Evandrou ${ }^{2,3}$ and Athina Vlachantoni ${ }^{2,3}$ \\ ${ }^{1}$ Department of Sociology, University of Munich (LMU), Munich, Germany, ${ }^{2}$ ESRC Centre for Population \\ Change, Faculty of Social Sciences, University of Southampton, Southampton, UK and ${ }^{3}$ Centre for Research \\ on Ageing, Faculty of Social Sciences, University of Southampton, UK \\ ${ }^{*}$ Corresponding author. Email: valeria.bordone@lmu.de
}

(Accepted 24 August 2018; first published online 8 October 2018)

\begin{abstract}
Caring for one's grandchildren has become a more common experience for individuals partly as a result of a longer overlap between the lives of grandparents and their grandchildren. Existing research shows that around 50 per cent of grandparents engage in some grandparental child care in most European countries, however, this proportion is higher among older people with a migrant background, partly due to greater economic necessity among migrant families. Research has also highlighted ethnic differences in parents' childcare selection, even after controlling for their socio-economic status. Building on these strands of work, this paper investigates the differences in the use of (grandparental) child care among parents from different Black and Minority Ethnic (BME) groups in the United Kingdom, using data from Understanding Society. The results show that parents from Other White, Indian, Pakistani, Bangladeshi and African communities are less likely to use child care than White British parents, while the opposite is true for Caribbean parents. However, among parents using child care, individuals from the Other White, Caribbean and African groups are less likely than the White British majority to be using grandparental child care as a supplement to other child-care types, or on its own. Ethnic differentials in the use of child care per se and grandparental child care in particular, have significant policy implications, and may mask other kinds of ethnic differences.
\end{abstract}

Keywords: child care; grandparent; ethnicity; minority ethnic groups; Understanding Society

\section{Introduction}

Increasing longevity has brought together an enlarged timespan of overlap of grandparents' lives with those of their grandchildren (Timonen and Arber, 2012). Despite some differences in the frequency of engagement in grandparental child care between countries, the literature has shown that the proportion of grandparents engaged in some grandparental child care is around 50 per cent in European countries and the United States of America (USA) (Hank and Buber, 
2009; Bordone et al., 2017). Recent evidence has also pointed to an important role, within these countries, of the origin of grandparents. For example, Bordone and de Valk (2016) showed that grandparental child care in Europe occurs significantly more often among parent-child dyads of migrant origin than is the case for the majority population. Acknowledging that grandparental child care may represent both practical help and emotional-associational bonds, they interpret this result as a consequence of a greater economic necessity among migrant families, but they also recognise the role of family norms in raising children among different origins groups (e.g. Treas and Mazumdar, 2004; Kagitçibasi, 2005). Other literature in this area has focused on ethnic differences in child-care selection (e.g. Hofferth et al., 1994; Liang et al., 2000), highlighting that Black families in the USA are more likely to select child-care centres than families from other ethnic groups, even after controlling for the parents' socio-economic status.

The parents' choice of the type of child care to be used, and the role of grandparental child care in such arrangements, is determined by a range of factors which may relate to the existence of grandparents in the first place, as well as the children's characteristics, in particular their age that might correlate with their types of need. Studies consistently show that grandparent-provided child care is less likely among children below age one (compared to children ages one or two), more likely among preschool grandchildren (e.g. Silverstein and Marenco, 2001) and it generally decreases afterwards. Other potentially relevant demographic characteristics, such as the child's gender, appear to be unrelated to grandparent caregiving. As could be expected, the likelihood of caring decreases unambiguously with increasing geographic distance between the older and the younger generations, particularly so if regular grandchild care is considered (for a review, see Hank and Buber, 2009).

Socio-economic and demographic characteristics at the parents' level may also play a relevant role in determining the choice to make use of grandparental child care. Younger parents are more likely to use grandparental child care (e.g. Baydar and Brooks-Gunn, 1998; Vandell et al., 2003). Ambiguous evidence exists regarding the significance of education, single parenthood and family income for using grandparental child care (e.g. Kuhlthau and Mason, 1996; Vandell et al., 2003; Hank and Buber, 2009).

Moreover, previous research has noted that grandparental child care is positively associated with maternal employment (e.g. Kuhlthau and Mason, 1996; Vandell et al., 2003), being fundamental for women in enabling them to juggle family and work, especially in countries where grandparents substitute (scarce) formal child care (Aassve et al., 2012; Arpino et al., 2014; Geurts et al., 2015). However, distinguishing further between full-time and part-time employment does not appear to yield different results.

Against this background, this paper addresses the following research question:

- Are there ethnic differences in the use of grandparental child care, after controlling for the mother's participation in the labour market?

The rest of the paper is structured as follows: evidence on the provision of grandparental child care in the United Kingdom (UK) and Europe is discussed in the next section, followed by a consideration of the role of ethnicity in this area. The 
subsequent section provides an outline of the data and methodology used in the analysis. This is followed by the presentation of the results, with the final section critically discussing the findings of the paper and their implications for the design of social policies aimed at supporting parents and grandparents alike.

\section{The provision of grandparental child care in the UK and Europe}

Grandparents often have an important role for their families, satisfying the need for child care (Aassve et al., 2012; Arpino et al., 2014). In Europe, about 58 per cent of grandmothers and 50 per cent of grandfathers provide care to their grandchildren (for a review, see Glaser et al., 2010). Seen from the perspective of the middle generation, this means that only between 20 and 30 per cent of parents do not turn at all to grandparents to care for their own children (Bordone et al., 2017). Yet, despite this general common trend across Europe, countries differ in the extent to which grandparents care for their grandchildren. While the highest rate of grandparental engagement in Europe is found in Northern countries (Hank and Buber, 2009), care-giving grandparents in Mediterranean countries look after their grandchildren more frequently, often on a daily basis (Hagestad, 2006). In the UK, similarly to other Western European countries, grandparents generally play a complementary role to market (or public, e.g. in Germany and the Netherlands) services, showing middle levels in both intensive and occasional child care. In particular, 17 per cent of British grandparents with a grandchild under 16 provide intensive levels of child care of at least ten hours a week and around one in 30 provides full-time care to a grandchild (Wellard, 2011).

This heterogeneity in the role of grandparents as providers of child care may relate to the policy context as well as to the institutional aspects of female labour force participation (Bordone et al., 2017). In the UK, public support for families is varied but less universal than in Nordic countries, and child care coverage is often provided by the market. Moreover, one in four English grandparents aged 50 and over are in paid work, compared with an average of just one in seven across Europe. Only Denmark and Sweden have a higher percentage of working grandparents (Glaser et al., 2010). As noted by Arpino et al. (2014), grandparental child care may depend on the grandparents' willingness and ability to look after their grandchildren, but also on the parents' preferences regarding the extent to which they wish to 'externalise' child care, i.e. arrange for child care to be provided outside the household and family context. In contexts with strong family ties and low employment rates, especially among women, a higher preference for the most internalised type of child care (i.e. women taking care of the children themselves) is observed. Women who participate in the labour market may either choose the next more internal child-care type, which may be grandparental child care, or the most external type of (formal) child care, which may be provided by the public or private sector. Although 'social conventions' of grandparenthood nowadays play a rather marginal role in the arrangements of grandparental child care in comparison with 'opportunity' and 'need structures' in terms of, for example, young mothers' employment (Silverstein et al., 2003), these preferences may also depend on cultural aspects linked to the cultural context and possibly ethnicity. 


\section{The role of ethnicity in grandparental child-care provision}

The use of ethnicity as a distinguishing characteristic of individuals requires careful consideration. Wimmer (2008) defines an ethnic group as a group sharing common characteristics, such as religious affiliation, language and cultural norms, all of which distinguish a specific group from others, thereby denoting difference. Ethnicity is also related to other complex concepts which are largely selfdetermined, such as one's race, nationality, migration history and heritage, as well as to the more formal concept of citizenship (Agarin, 2014; Maas, 2016; Piętka-Nykaza and McGhee, 2016). As such, ethnicity may be conceptualised as one part of an individual's identity - an approach favoured by psychologists; or as part of the broader social stratification through attaching particular outcomes to groups with particular characteristics - an approach which tends to be used by other researchers and by policy makers (Burton et al., 2008). Yet ethnicity, as Craig et al. (2012: 23) note, is not a characteristic that people 'have', rather it refers to 'dynamic processes of self-identity and differentiation involving the negotiation of boundaries of inclusion and exclusion between groups [and] [ $\mathrm{t}$ ]hese boundaries are fluid and shift according to the context of social interaction and struggles over power and resources over time'. Such a dynamic, inclusive definition of ethnicity facilitates a broader understanding of how individuals' minority ethnic status might be related to their choices about child care, and how such choices might potentially set them apart from the majority population.

The use of ethnicity to distinguish groups of individuals who are different on one or more characteristics from the majority population is particularly important for the study of child-care arrangements made by working-age individuals. This is because ethnicity is directly related to the accumulation of experiences and resources for individuals across their lifecourse (Phillipson, 2015). In the case of minority ethnic populations, such an accumulation has, more often than not, pointed at a cultural, financial and social disadvantage, although critical differences exist both between the two genders and between individuals from different cohorts (e.g. Vlachantoni et al., 2017). One's ethnic background can help to unravel complex patterns and behaviours which can affect financial resources and outcomes across the lifecourse and in later life (e.g. Evandrou, 2000; Baldassar, 2007).

Academic literature has highlighted ethnic differences in terms of employment behaviour, economic resources, as well as patterns of informal care provision towards family members (Evandrou, 2000; Smith et al., 2000; Bécares et al., 2012). In terms of employment, Vlachantoni et al. (2015) showed that 86 per cent of Indian men aged 25-59 are in paid work, compared to 68 per cent of Caribbean men in the same age group. Among women of the same age, 30 per cent of Pakistani and Bangladeshi women compared to 74 per cent of White British women are in work. Once they are in work, individuals from most minority ethnic groups are more likely to be self-employed and to work part-time, which combine to result in lower earnings than their White counterparts (Pension Policy Institute, 2003). Ethnic differentials in paid work, which can directly affect individuals' ability to pay for child care, can interact with particular types of living arrangements and distinct cultural/religious values relating to the provision of care within the family. Evidence from the 2001 UK Census showed that the average 


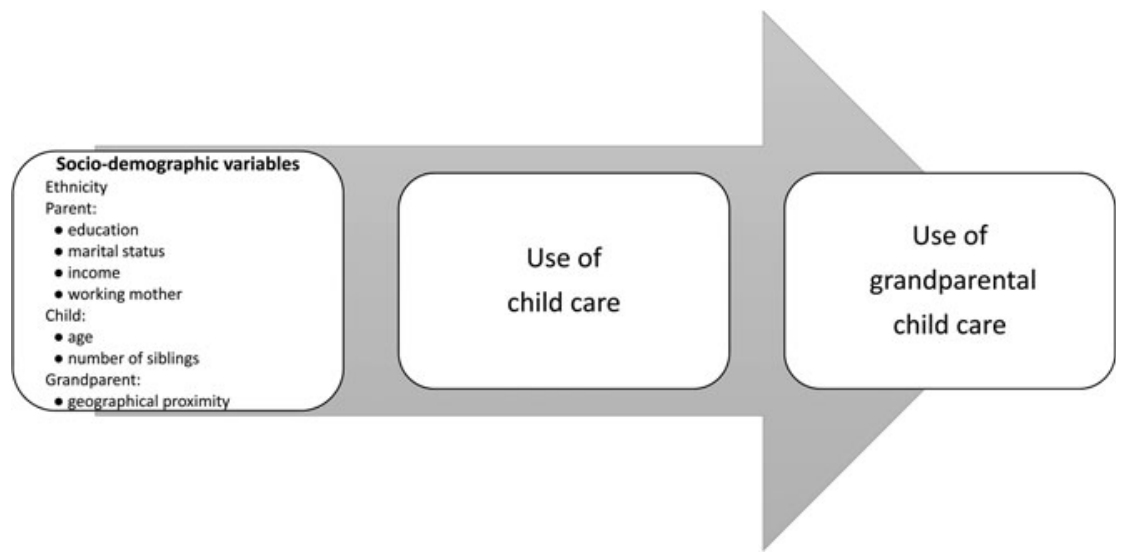

Figure 1. Conceptual framework.

household size among Bangladeshi families was 4.5 persons, followed by 4.1 among Pakistanis and 3.3 among Indians (Office for National Statistics, 2006), while overcrowding was more likely to be experienced in Bangladeshi compared to White British households (44\% compared to $6 \%$ ). At the same time, literature shows that individuals from ethnic minorities are more likely to engage in informal care of family members than individuals from the White British community (Willis et al., 2013), while the role of grandparents is particularly important within transnational families spread across geographical boundaries (Lie, 2010).

Drawing on the previous literature, our study explores similarities and differences in the use of child care and, among those parent-child dyads using child care, in their use of grandparental child care (either in addition to other types of child care or on its own).

Figure 1 outlines the conceptual framework of the research and proposes that an individual's use of child care, which acts as a prerequisite for using grandparental child care, may be determined by ethnicity. Other than on this factor, (grandparental) child care may derive from a range of socio-demographic characteristics of the parents, such as education, marital status, income and activity status of the mother, as well as from characteristics of the child, including their age and number of siblings. An individual's use of grandparental child care may be additionally determined by the availability of grandparents, in terms of their geographical distance. The variables used in this paper are explained in the next section in greater detail. Drawing on previous literature on cross-country differences in intergenerational contact being shaped by social norms (e.g. Bordone, 2012), we acknowledge that the effect of ethnicity may be mediated through unobservable variables, e.g. 'culture' (norms, preferences and trust) which, however, we cannot measure.

\section{Data and methods}

The paper uses data from Understanding Society, which is a nationally representative survey of more than 100,000 members of more than 40,000 households in the 
UK (University of Essex et al., 2014; see also https://www.understandingsociety.ac. $\mathrm{uk} /$ ). The sample of Understanding Society used here includes the General Population (GP) and an Ethnic Minority Boost sample (EMB). The addresses of the sample were randomly selected from the Postcode Address File in Great Britain and the Land and Property Services Agency list of domestic properties in Northern Ireland. In each household, all individuals aged ten years and over were eligible for interview. Computer Aided Personal Interview was used to administer the household and individual adult questionnaires. The response rates for the GP and EMB were 82 and 73 per cent, respectively (Boreham et al., 2012). The analysis in this paper includes respondents from Waves 1-5 (20092015), with available information about the use of child care. In this survey, child care is defined as care for the child carried out by anyone other than the parent and/or their partner. The survey asks parents about the usual arrangements for looking after their children during school term-time. While for younger children this would usually correspond to the care arrangements in school holidays, for school-age children this question captures more regularly used forms of care, both formal or informal. For each child, we use the information on the three most used types of care.

In line with our conceptual framework (Figure 1), we first focus on whether or not the respondent uses child care for their children. The analytical sample for the use of child care includes 68,888 parent-child dyads, where parents are aged between 18 and 60 years old were interviewed at least once over the five waves, and are responsible for at least one child below 15 years old (i.e. they are 'at risk' of using child care). The threshold of 15 is defined in the data, as there is a specific question about being responsible for children aged 15 or less, and is comparable with existing research in this area (see Bordone et al., 2017). Among the total number of dyads, 12,492 dyads came from the five ethnic groups purposely recruited through the EMB of the survey (Indian, Pakistani, Bangladeshi, Caribbean and African). In the second step of the analysis, where the use of grandparental child care was explored, only those dyads who make use of (any) child care and have provided information on such care, were included, totalling 25,145 dyads. An overview of the various types of child care used by dyads using child care is shown in Table 1. Since the same parent may be considered in more than one parent-child dyad and the same parent-child dyad may be included more than once in the sample (if interviewed in more than one wave), clustered standard errors were used (Cameron and Trivedi, 2010). In a robustness check, the same models were run considering each parent-child dyad only at their first interview $(\mathrm{N}=23,184$ for the analysis of (any) child care use; $\mathrm{N}=7,891$ for the analyses of grandparental child care on the sub-sample using child care; results available on request from the corresponding author). As the results were very similar to those presented in the paper, we decided to keep the largest sample in order to increase the explanatory power of the analysis.

A set of logistic regressions was used in order to examine the factors associated with the use of any child care, and specifically grandparental child care, among the separate Black and Minority Ethnic (BME) groups. The binary dependent variables included the following: 
Table 1. Descriptive statistics on the use of different types of child care, by ethnicity

\begin{tabular}{|c|c|c|c|c|c|c|c|c|c|}
\hline & $\begin{array}{l}\text { White } \\
\text { British }\end{array}$ & $\begin{array}{l}\text { Other } \\
\text { White }\end{array}$ & Indian & Pakistani & Bangladeshi & Caribbean & African & Other & Missing \\
\hline & \multicolumn{9}{|c|}{ Percentages } \\
\hline Grandparental child care & 41.5 & 23.1 & 27.0 & 28.1 & 23.6 & 18.46 & 7.7 & 24.7 & 46.6 \\
\hline Nursery school/class & 10.6 & 13.5 & 12.5 & 11.3 & 9.7 & 9.0 & 13.6 & 14.6 & 11.8 \\
\hline Special day school & 0.5 & 0.7 & 0.3 & 0.5 & 0.7 & 0.7 & 0.6 & 0.5 & 0.4 \\
\hline Day nursery/crèche & 6.8 & 10.3 & 7.6 & 6.2 & 7.6 & 3.7 & 5.3 & 7.0 & 11.4 \\
\hline Playground/pre-school & 3.8 & 4.6 & 1.9 & 4.4 & 4.9 & 2.0 & 2.1 & 2.8 & 3.8 \\
\hline Childminder & 10.7 & 7.9 & 6.9 & 5.8 & 0.7 & 13.0 & 17.6 & 9.2 & 11.6 \\
\hline Nanny/au pair & 1.8 & 6.1 & 3.0 & 0 & 2.8 & 1.8 & 2.8 & 8.4 & 1.2 \\
\hline Baby-sitter at home & 2.4 & 7.1 & 0.7 & 1.8 & 0 & 2.2 & 3.4 & 1.7 & 2.1 \\
\hline Breakfast club on school site & 11.4 & 7.7 & 10.8 & 4.4 & 6.3 & 19.6 & 13.0 & 12.0 & 9.4 \\
\hline Breakfast club not on school site & 4.4 & 4.5 & 5.9 & 3.7 & 4.2 & 9.3 & 8.8 & 6.5 & 3.7 \\
\hline Holiday club & 1.1 & 1.0 & 1.4 & 0 & 0 & 2.9 & 1.9 & 1.6 & 0.7 \\
\hline Ex-partner & 3.7 & 1.6 & 0.5 & 1.8 & 2.8 & 4.6 & 2.5 & 4.4 & 2.8 \\
\hline Older siblings & 2.3 & 5.3 & 0.8 & 0.9 & 3.5 & 5.1 & 1.8 & 1.0 & 1.8 \\
\hline Other relative & 6.2 & 3.5 & 6.4 & 17.2 & 19.4 & 8.4 & 11.9 & 4.4 & 7.6 \\
\hline Friend/neighbour & 5.9 & 9.4 & 7.4 & 5.3 & 4.9 & 6.6 & 13.0 & 7.1 & 6.0 \\
\hline Other nursery & 0.2 & 0.3 & 0 & 0.5 & 0 & 1.8 & 1.0 & 0.3 & 0.1 \\
\hline Other child-care provider & 0.5 & 0.3 & 0.7 & 3.0 & 2.8 & 1.3 & 1.0 & 0.8 & 0.5 \\
\hline $\mathrm{N}$ & 14,636 & 998 & 593 & 435 & 144 & 547 & 831 & 1,149 & 5,822 \\
\hline
\end{tabular}


(1) Whether child care (as defined above) is used for the child in the dyad.

(2) Whether, among dyads using child care, grandparental child care is used (along with other types of child care).

(3) Whether, among dyads using child care, grandparental child care is used as the only form of child care.

The key explanatory variable is ethnicity which, in its derived form, includes the following categories: White British (reference category); Other White; Indian; Pakistani; Bangladeshi; Caribbean; African; Other. An additional category of 'Missing' was included, accounting for cases where no information about ethnicity is available, but for which we know whether (grandparental) child care was used. A number of control variables is included in the analyses, following previous evidence (in particular, Hank and Buber, 2009; Arpino and Bordone, 2014; Bordone et al., 2017). At the parents' level, the following controls were included, as they have been shown to be influential in past research in this area: education (=1 if A-level, Higher or degree; $=0$ otherwise) (Burton et al., 2008; Arpino and Bordone, 2014); household income (three dummies consider the income tertiles) (Berthoud, 1998); and living arrangements, distinguishing between living alone and living with a partner (Evandrou, 2000). Taking into account the literature emphasising the importance of the mother's economic activity status in the choices regarding child care (Aassve et al., 2012; Arpino et al., 2014; Bordone et al., 2017), the analysis also accounted for whether the mother of the child is working $(=1$ if employed or self-employed; $=0$ otherwise). Previous research has shown that the demand for child care is directly affected by the child's age and whether they have siblings (Bordone et al., 2017), and as such, the analysis controls for the child's age (continuous variable) and the number of siblings (none (reference category); one; two or more).

When focusing specifically on the use of grandparental child care, an indicator of the geographical proximity of the adult in the dyad to the parents/parents-in-law (i.e. the grandparents of the child in the dyad) has been taken into account, which has been shown to be critical in existing work (e.g. Hank and Buber, 2009). This indicator distinguishes between having at least one parent/parent-in-law in the household; living within half an hour from the nearest parent/parent-in-law (reference category); having the nearest parent/parent-in-law living between 30 minutes and one hour away; between one and two hours away; or more than two hours away. Information on the geographical distance to the parent(s)/parent(s)-in-law is only available in Waves 1,3 and 5 , where the 'family networks' module is included in the survey. In order not to lose observations, where possible, we used the information at the previous wave for the waves with missing values. Additionally, we created the category of 'no grandparents/missing' where there is no information about the geographical distance either because no grandparent is alive for that child or because information concerning the proximity is missing. Additional analyses excluding Waves 2 and 4, where proximity information was not available, provided very similar results on the variables of interest, and therefore, we decided to proceed with the analysis on the largest possible sample (results available on request from the corresponding author). 
A number of variables were also included in preliminary analysis, but did not improve the models and were excluded from the final analysis. The results are shown as robustness checks. Firstly, the migration background of the respondent was considered, describing them as belonging to a second generation if they were born in the UK, but their parents were not; as a short-term migrant if they were not born in the UK and moved to the UK less than 14 years before than the interview; as a long-term migrant if they were not born in the UK and moved to the UK at least 14 years before than the interview; and as native (reference category) if both the respondent and their parents were born in the UK. The threshold of 14 years was chosen as it corresponds to the median number of years that migrants in the sample had spent in the UK (50th percentile). Secondly, the ethnicity of both partners (i.e. the respondent and their partner) was considered by including a variable which has value 0 if living alone; 1 if living with a White British partner; 2 if the partner is not White British; 3 if no information is available about the partner's ethnicity. Thirdly, the analysis considered whether at least one parent has long-standing illness or impairment ( 1 if yes; 0 if not). Finally, preliminary analyses also controlled for whether at least one grandchild's sibling is cared for by grandparents, but this variable was shown to be highly correlated with grandparental child care in the dyad and was subsequently excluded from the analysis.

\section{Results}

\section{Descriptive analyses}

About 37.5 per cent of parents in the sample use (any type of) child care, ranging from about 42 per cent of White British and Caribbean respondents to 6 per cent among Bangladeshi respondents (Table 2, upper panel). Among respondents using child care (Table 2, lower panel), 14.4 per cent use grandparental child care and 8.1 per cent use only grandparental child care for their children. While 41.5 per cent of White British respondents use grandparental child care, less than 8 per cent of African respondents do so.

Exploring ethnic differences in greater detail, the analysis shows that Indian, Pakistani, Bangladeshi and African individuals are less likely to use child care than White British individuals (e.g. 25\% of Indian parents use any child care compared to $41 \%$ of White British parents). Among those from BME communities using (any type of) child care, the likelihood of using grandparental child care is also lower than among White British individuals (e.g. 28\% among Bangladeshi parents compared to $42 \%$ of White British parents). Caribbean persons are more likely to use child care than persons from other ethnic groups, however, once they use child care, such care is less likely to be grandparental child care than for most of the other ethnic groups (with the exception of Africans). Individuals of Other White origin do not differ much from White British individuals in their probability of using child care ( $37 \%$ versus $41 \%$ ), nevertheless among those who use child care, grandparental child care is less likely to be used among Other White persons than among White British persons (23\% versus $42 \%$ ).

The reasons behind these differences may be complex, including demographic and socio-economic factors which may affect the availability of grandparents to 
Table 2. Descriptive statistics of the dependent and independent variables included in the analyses, by ethnicity, on the whole sample and considering only the sub-sample using child care

\begin{tabular}{|c|c|c|c|c|c|c|c|c|c|}
\hline & White British & Other White & Indian & Pakistani & Bangladeshi & Caribbean & African & Other & Missing \\
\hline \multicolumn{10}{|l|}{ Whole sample: } \\
\hline Working mother & 63.7 & 59.9 & 60.9 & 19.2 & 17.3 & 58.8 & 46.3 & 48.8 & 66.6 \\
\hline Living with partner & 61.7 & 73.1 & 90.2 & 91.4 & 90.7 & 40.4 & 55.5 & 66.6 & 82.8 \\
\hline Child age (mean) & 7.7 & 7.0 & 7.4 & 7.4 & 7.6 & 8.1 & 7.2 & 7.0 & 6.5 \\
\hline \multicolumn{10}{|l|}{ Number of siblings: } \\
\hline 0 & 28.0 & 25.3 & 23.4 & 13.1 & 14.9 & 34.7 & 17.2 & 28.89 & 36.0 \\
\hline 1 & 45.6 & 47.9 & 51.1 & 34.2 & 32.9 & 41.5 & 34.62 & 46.1 & 40.7 \\
\hline $2+$ & 26.4 & 26.8 & 25.6 & 52.8 & 52.2 & 23.8 & 48.2 & 25.1 & 23.3 \\
\hline High (3rd tertile) & 34.9 & 38.4 & 36.1 & 18.2 & 18.6 & 24.1 & 21.6 & 29.0 & 38.9 \\
\hline $\mathrm{N}$ & 36,345 & 2,725 & 2,394 & 3,526 & 2,344 & 1,351 & 2,877 & 3,655 & 13,671 \\
\hline$\%$ & 52.8 & 4.0 & 3.5 & 5.1 & 3.4 & 2.0 & 4.2 & 5.3 & 19.9 \\
\hline \multicolumn{10}{|l|}{ Among those using child care: } \\
\hline Also grandparental child care & 41.5 & 23.1 & 27.0 & 28.1 & 23.6 & 18.5 & 7.7 & 24.7 & 46.6 \\
\hline Only grandparental child care & 23.5 & 14.5 & 19.7 & 18.2 & 13.2 & 8.8 & 4.6 & 15.8 & 25.3 \\
\hline
\end{tabular}




\begin{tabular}{|c|c|c|c|c|c|c|c|c|c|}
\hline Working mother & 81.2 & 77.5 & 85.3 & 51.7 & 63.2 & 75.1 & 72.0 & 75.5 & 86.2 \\
\hline Living with partner & 65.9 & 78.3 & 90.6 & 81.8 & 86.8 & 41.7 & 57.0 & 64.6 & 86.1 \\
\hline High education & 25.4 & 16.6 & 9.6 & 18.6 & 12.5 & 40.4 & 38.0 & 30.7 & 22.5 \\
\hline Child age (mean) & 6.2 & 5.7 & 6.1 & 5.9 & 5.9 & 7.1 & 6.0 & 5.8 & 5.2 \\
\hline \multicolumn{10}{|l|}{ Number of siblings: } \\
\hline 0 & 22.9 & 22.4 & 20.9 & 12.2 & 25.0 & 31.18 & 17.8 & 27.5 & 33.3 \\
\hline 1 & 54.0 & 56.3 & 58.4 & 49.2 & 33.3 & 45.7 & 43.9 & 51.9 & 48.0 \\
\hline $2+$ & 23.1 & 21.4 & 20.7 & 38.6 & 41.7 & 23.2 & 38.3 & 20.6 & 18.7 \\
\hline \multicolumn{10}{|l|}{ Household income: } \\
\hline Low (1st tertile) & 23.4 & 15.6 & 15.0 & 45.5 & 31.9 & 40.6 & 37.8 & 27.7 & 20.0 \\
\hline Medium (2nd tertile) & 32.3 & 34.7 & 28.2 & 31.0 & 36.1 & 33.5 & 30.7 & 31.8 & 31.4 \\
\hline High (3rd tertile) & 44.4 & 49.7 & 56.8 & 23.5 & 31.9 & 26.0 & 31.5 & 40.6 & 48.6 \\
\hline \multicolumn{10}{|l|}{ Proximity to grandparents: } \\
\hline$<30$ minutes & 72.0 & 41.8 & 46.5 & 62.1 & 33.3 & 49.4 & 14.2 & 36.6 & 53.1 \\
\hline 30 minutes to 1 hour & 8.4 & 3.4 & 7.9 & 7.1 & 6.9 & 14.4 & 4.5 & 8.7 & 5.3 \\
\hline $1-2$ hours & 6.54 & 6.1 & 6.2 & 6.0 & 19.4 & 5.5 & 4.2 & 7.1 & 5.3 \\
\hline$>2$ hours & 9.4 & 44.6 & 34.4 & 18.4 & 32.6 & 26.1 & 65.5 & 42.48 & 7.9 \\
\hline No grandparents/missing information & 3.7 & 4.1 & 4.9 & 6.4 & 7.6 & 4.6 & 11.7 & 5.2 & 28.5 \\
\hline $\mathrm{N}$ & 14,636 & 988 & 593 & 435 & 144 & 547 & 831 & 1,149 & 5,822 \\
\hline$\%$ & 58.2 & 3.9 & 2.4 & 1.7 & 0.6 & 2.2 & 3.3 & 4.6 & 23.2 \\
\hline
\end{tabular}

Source: Authors' analysis of Understanding Society (USOC) Waves 1-5 (2009-2015). 
provide care in different ethnic groups, and the demand for such care in the first place. For example, Table 2 (upper panel) shows that although there are no evident differences in the mean age of the children across the different ethnic group samples, nevertheless 28 per cent of White British children have no siblings, compared to 13 per cent of Pakistani and 15 per cent of Bangladeshi children, indicating different family sizes between the ethnic groups. Large differences also permeate the living arrangements of the parent in the dyad which can directly affect the supply of child care at home, with more than 90 per cent of respondents from the three South Asian groups living with a partner, compared to just over 40 per cent of Caribbean and 56 per cent of African respondents. In terms of socio-economic characteristics, 64 per cent of the children in the White British sub-group compared to 17 per cent of their Bangladeshi counterparts have a working mother, while about 45 per cent of Pakistani, Bangladeshi and Caribbean parent-child dyads live in low-income households compared to about one-third of White British parent-child dyads.

Focusing on dyads using child care (Table 2, lower panel), it can be seen that respondents in such a sub-sample are generally more likely to be living with a partner, with the exception of those from a Pakistani, Bangladeshi and Other ethnic origin. Similarly, the proportion of working mothers is higher across all groups, albeit with persistent ethnic differentials (e.g. more than $80 \%$ of White British and Indian mothers are working, compared to 52\% of Pakistani and $63 \%$ of Bangladeshi mothers), while the proportion of low-income households is lower across all groups except the Pakistani group. Importantly, while 72 per cent of White British parentchild dyads have at least one (grand)parent or (grand)parent-in-law living within 30 minutes, this is the case for only 14 per cent of African respondents. In order to assess the relative importance of a range of characteristics associated with the respondent's use of child care and grandparental child care specifically, the next part of the paper presents results from multivariate analyses.

\section{Multivariate analyses}

The associations found between ethnic groups and the use of child care in the descriptive analysis are confirmed by the logistic models, as shown in Table 3. Interestingly, the negative effect on grandparental child care of belonging to an ethnic group different from the White British group remains after controlling for geographical proximity to grandparents. In particular, the findings confirm that Indian, Pakistani, Bangladeshi and African individuals are significantly less likely to use child care than White British individuals (e.g. the odds of using child care among Bangladeshi parents are about 0.2 times the odds among White British parents, $p<0.001$ ) (Table 3, Child care use column). However, once individuals from such groups use child care, their likelihood of using grandparental child care alongside other types of child care is statistically significantly different from that of White British individuals for African, Caribbean and Indian dyads (Table 3, Grandparental child care column). Also in line with the descriptive analysis, Table 3 (Only grandparental child care column) shows that, once using child care, Caribbean parents are less likely to use only grandparental child care than White British parents (odds ratio $(\mathrm{OR})=0.394, p<0.001$ ). 
Table 3. Odds ratios of the logistic analyses on using child care; among those using child care, using grandparental child care; and among those using child care, only using grandparental child care

\begin{tabular}{|c|c|c|c|}
\hline & Child care use & $\begin{array}{l}\text { Grandparental } \\
\text { child care }\end{array}$ & $\begin{array}{l}\text { Only grandparental } \\
\text { child care }\end{array}$ \\
\hline & \multicolumn{3}{|c|}{ Odds ratios (clustered standard errors) } \\
\hline \multicolumn{4}{|l|}{$\begin{array}{l}\text { Ethnicity (Ref. White } \\
\text { British): }\end{array}$} \\
\hline Other White & $0.780^{\star \star \star}(0.054)$ & $0.711^{\star \star}(0.083)$ & $0.856(0.116)$ \\
\hline Indian & $0.439^{\star \star \star}(0.034)$ & $0.774 \dagger(0.105)$ & $1.116(0.168)$ \\
\hline Pakistani & $0.402^{\star \star \star}(0.037)$ & $0.768(0.138)$ & $0.907(0.187)$ \\
\hline Bangladeshi & $0.192^{\star \star \star}(0.026)$ & $0.899(0.283)$ & $0.888(0.338)$ \\
\hline Caribbean & $1.207^{\star}(0.110)$ & $0.391^{\star \star \star}(0.057)$ & $0.394^{\star \star \star}(0.080)$ \\
\hline African & $0.721^{\star \star \star}(0.053)$ & $0.338^{\star \star \star}(0.063)$ & $0.409^{\star \star \star}(0.098)$ \\
\hline Other & $0.750^{\star \star \star}(0.044)$ & $0.820 \dagger(0.085)$ & $1.085(0.127)$ \\
\hline Missing & $0.904^{\star \star}(0.031)$ & $1.297^{\star \star \star}(0.064)$ & $1.191^{\star \star}(0.066)$ \\
\hline $\begin{array}{l}\text { Working mother } \\
\text { (Ref. Not) }\end{array}$ & $4.923^{\star \star \star}(0.162)$ & $1.316^{\star \star \star}(0.071)$ & $1.354^{\star \star \star}(0.086)$ \\
\hline $\begin{array}{l}\text { With partner (Ref. Living } \\
\text { alone) }\end{array}$ & $0.907^{\star \star}(0.033)$ & $0.931(0.050)$ & $0.967(0.060)$ \\
\hline High education (Ref. Low) & $1.717^{\star \star \star}(0.064)$ & $0.911 \dagger(0.046)$ & $0.699^{\star \star \star}(0.041)$ \\
\hline \multicolumn{4}{|l|}{$\begin{array}{l}\text { Household income } \\
\text { (Ref. Low, 1st tertile): }\end{array}$} \\
\hline Middle (2nd tertile) & $1.198^{\star \star \star}(0.043)$ & $1.116^{\star}(0.060)$ & $1.099(0.066)$ \\
\hline High (3rd tertile) & $1.938^{\star \star \star}(0.072)$ & $1.065(0.058)$ & $0.904(0.056)$ \\
\hline Child age & $0.872^{\star \star \star}(0.002)$ & $1.012^{\star \star}(0.004)$ & $1.055^{\star \star \star}(0.005)$ \\
\hline \multicolumn{4}{|l|}{$\begin{array}{l}\text { Number of siblings } \\
\text { (Ref. 0): }\end{array}$} \\
\hline 1 & $1.663^{\star \star \star}(0.044)$ & $0.743^{\star \star \star}(0.029)$ & $1.020(0.044)$ \\
\hline $2+$ & $1.235^{\star \star \star}(0.047)$ & $0.465^{\star \star \star}(0.027)$ & $0.802^{\star \star \star}(0.053)$ \\
\hline \multicolumn{4}{|l|}{$\begin{array}{l}\text { Proximity to } \\
\text { grandparents (Ref. }<30 \\
\text { minutes): }\end{array}$} \\
\hline 30 minutes to 1 hour & & $0.326^{\star \star \star}(0.024)$ & $0.301^{\star \star \star}(0.032)$ \\
\hline $1-2$ hours & & $0.225^{\star \star \star}(0.021)$ & $0.185^{\star \star \star}(0.026)$ \\
\hline$>2$ hours & & $0.116^{\star \star \star}(0.009)$ & $0.156^{\star \star \star}(0.016)$ \\
\hline $\begin{array}{l}\text { No grandparents/ } \\
\text { missing }\end{array}$ & & $0.480^{\star \star \star}(0.033)$ & $0.617^{\star \star \star}(0.049)$ \\
\hline $\mathrm{N}$ & 68,888 & 25,145 & 25,145 \\
\hline
\end{tabular}

Notes: All models also include an indicator for the wave of interview. Ref.: reference category. Source: Authors' analysis of Understanding Society (USOC) Waves 1-5 (2009-2015).

Significance levels: $\dagger p<0.1,{ }^{\star} p<0.05,{ }^{\star \star} p<0.01,{ }^{\star \star \star} p<0.001$. 
The control variables suggest the expected associations with the probability of using child care and specifically grandparental child care. For example, living with one's partner reduces the likelihood of using any child care compared to living alone ( $\mathrm{OR}=0.907, p<0.01)$, although it is not statistically associated with the use of grandparental child care. The higher the child's age, the less likely it is that parents will use any child care, however, among those using child care, there is a positive association between child's age and the use of grandparental child care. Children with siblings are significantly more likely to use (any) child care compared to single children, however, the higher the number of siblings the lower the chance of using grandparental child care (along with other types of child care or on its own). Critically, the likelihood of using grandparental child care (either in combination with other types of child care or on its own) decreases the further away the grandparent lives from the grandchild (e.g. the dyads living between 30 minutes and one hour or between one and two hours away from the nearest grandparent are 68 and $78 \%$ less likely, respectively, to use grandparental child care along with other types of child care, compared to those living within 30 minutes of a grandparent, $p<0.001$ ).

Two socio-economic factors deserve particular attention. Firstly, the fact that the mother is working is associated with a much higher likelihood of using child care as well as grandparental child care, either as an additional form of child care or as the only one. For instance, in cases where the household includes a working mother, the odds of using grandparental child care alongside other types of child care are 1.31 times the odds among households without a working mother $(p<0.001)$. Secondly, the effect of the parent's education presents an intricate picture. Higher education is associated with a higher likelihood of using child care per se, but is significantly negatively associated with the child being cared for by their grandparents, especially if this is the only form of child care used. Such findings indicate a complex effect of the parents' education, which may be mediated by greater employment opportunities for highly educated individuals, and a greater ability to dedicate financial resources to paid child care.

\section{Robustness checks}

Results from the robustness checks where we controlled for the migration background of the respondent show that, on average, first-generation migrants are less likely to use child care than native British respondents; while we found no difference in the likelihood of using (any) child care between second-generation migrants and native British respondents. Among dyads using child care, native British respondents are significantly more likely to use only grandparental child care than dyads with a migration background (Table 4). We also found that, for migrants, there is an effect of the time spent in the UK: the more time they have spent in the country, the lower the difference from native British respondents. This variable was also interacted with the ethnicity variable in order to understand their combined effect, but due to the small sample size in some sub-groups, several categories were dropped from the model (results not shown).

Other than one's own ethnicity, the ethnic group of one's partner may also be associated with the choice of child care. Indeed, when distinguishing between living 
Table 4. Odds ratios of the logistic analyses on using child care; among those using child care, using grandparental child care; and among those using child care, only using grandparental child care, controlling for migration background

\begin{tabular}{|c|c|c|c|}
\hline & Child care use & $\begin{array}{l}\text { Grandparental } \\
\text { child care }\end{array}$ & $\begin{array}{l}\text { Only grandparental } \\
\text { child care }\end{array}$ \\
\hline & \multicolumn{3}{|c|}{ Odds ratios (clustered standard errors) } \\
\hline \multicolumn{4}{|l|}{ Ethnicity (Ref. White British): } \\
\hline Other White & $1.097(0.125)$ & $0.847(0.143)$ & $1.105(0.211)$ \\
\hline Indian & $0.604^{\star \star \star}(0.075)$ & $0.924(0.177)$ & $1.522^{\star}(0.321)$ \\
\hline Pakistani & $0.542^{\star \star \star}(0.071)$ & $0.910(0.197)$ & $1.251(0.312)$ \\
\hline Bangladeshi & $0.268^{\star \star \star}(0.045)$ & $1.085(0.370)$ & $1.194(0.488)$ \\
\hline Caribbean & $1.468^{\star \star}(0.179)$ & $0.454^{\star \star \star}(0.082)$ & $0.540^{\star \star}(0.126)$ \\
\hline African & $1.044(0.124)$ & $0.418^{\star \star \star}(0.094)$ & $0.516^{\star}(0.147)$ \\
\hline Other & $0.987(0.102)$ & $0.958(0.142)$ & $1.427^{\star}(0.225)$ \\
\hline Missing & $1.266^{\star}(0.136)$ & $1.554^{\star \star}(0.241)$ & $1.618^{\star \star}(0.280)$ \\
\hline \multicolumn{4}{|l|}{$\begin{array}{l}\text { Migration background (Ref. Second } \\
\text { generation): }\end{array}$} \\
\hline Native & $0.971(0.092)$ & $1.138(0.145)$ & $1.498^{\star \star}(0.207)$ \\
\hline Migrant in the country $\leqslant 14$ years & $0.548^{\star \star \star}(0.064)$ & $0.837(0.202)$ & $1.361(0.389)$ \\
\hline Migrant in the country $>14$ years & $0.712^{\star \star}(0.080)$ & $0.872(0.162)$ & $1.258(0.283)$ \\
\hline Missing & $0.689^{\star \star \star}(0.062)$ & $0.945(0.135)$ & $1.094(0.189)$ \\
\hline Working mother (Ref. Not) & $4.919^{\star \star \star}(0.162)$ & $1.315^{\star \star \star}(0.071)$ & $1.357^{\star \star \star}(0.086)$ \\
\hline With partner (Ref. Living alone) & $0.917^{\star}(0.034)$ & $0.927(0.051)$ & $0.962(0.061)$ \\
\hline High education (Ref. Low) & $1.703^{\star \star \star}(0.064)$ & $0.915 \dagger(0.047)$ & $0.704^{\star \star \star}(0.042)$ \\
\hline \multicolumn{4}{|l|}{$\begin{array}{l}\text { Household income (Ref. Low, 1st } \\
\text { tertile): }\end{array}$} \\
\hline Middle (2nd tertile) & $1.196^{\star \star \star}(0.043)$ & $1.115^{\star}(0.060)$ & $1.099(0.066)$ \\
\hline High (3rd tertile) & $1.937^{\star \star \star}(0.072)$ & $1.064(0.058)$ & $0.905(0.057)$ \\
\hline Child age & $0.872^{\star \star \star}(0.002)$ & $1.012^{\star \star}(0.004)$ & $1.055^{\star \star \star}(0.005)$ \\
\hline \multicolumn{4}{|l|}{ Number of siblings (Ref. 0): } \\
\hline 1 & $1.663^{\star \star \star}(0.044)$ & $0.743^{\star \star \star}(0.029)$ & $1.019(0.044)$ \\
\hline $2+$ & $1.232^{\star \star \star}(0.047)$ & $0.465^{\star \star \star}(0.027)$ & $0.801^{\star \star \star}(0.053)$ \\
\hline \multicolumn{4}{|l|}{$\begin{array}{l}\text { Proximity to grandparents } \\
\text { (Ref. }<30 \text { minutes): }\end{array}$} \\
\hline 30 minutes to 1 hour & & $0.327^{\star \star \star}(0.024)$ & $0.302^{\star \star \star}(0.032)$ \\
\hline $1-2$ hours & & $0.225^{\star \star \star}(0.021)$ & $0.186^{\star \star \star}(0.026)$ \\
\hline$>2$ hours & & $0.118^{\star \star \star}(0.009)$ & $0.156^{\star \star \star}(0.016)$ \\
\hline No grandparents/missing & & $0.483^{\star \star \star}(0.033)$ & $0.617^{\star \star \star}(0.049)$ \\
\hline $\mathrm{N}$ & 68,888 & 25,145 & 25,145 \\
\hline
\end{tabular}

Notes: All models also include an indicator for the wave of interview. Ref.: reference category. Source: Authors' analysis of Understanding Society (USOC) Waves 1-5 (2009-2015).

Significance levels: $\dagger p<0.1,{ }^{\star} p<0.05,{ }^{\star \star} p<0.01$, ${ }^{\star \star \star} p<0.001$. 
with a White British partner and living with a partner from any other ethnicity, only the odds of the latter are negative and statistically significantly different from those among respondents living alone (Table 5). Although it would be potentially interesting to carry out models that account for the different ethnic combinations of couples in our sample, most of the respondents who are living with a partner do belong to the same ethnic group as the partner (e.g. about $77 \%$ of White British women are married to or live with White British men; among Indian women with a partner, almost $76 \%$ have an Indian one, $78 \%$ of Pakistani women have a Pakistani partner, $81 \%$ of Bangladeshi women have a partner of the same ethnic group and this holds true for almost $71 \%$ of African women). Only among women of Caribbean ethnicity is the proportion having a partner of the same ethnic group below 50 per cent. It is also interesting to note that the effect of our explanatory variable remains very similar to that reported in Table 3 once a control for partner's ethnicity is added.

Similarly, the results in Table 6 do not substantially differ from those of Table 3, despite including a control for long-standing illness or impairment of at least one of the parents. The odds for this variable are not statistically significant in any of the three models.

The final robustness checks consisted of carrying out the same analyses as in Table 3 by considering parent-child dyads only at first interview. Although the sample was significantly reduced, the results were qualitatively very similar to those presented in the main analyses (results available on request from the corresponding author).

\section{Discussion and conclusion}

The support between generations within the family is central in current academic as well as public debates, at a time when suggested solutions for overcoming the lack of, or the existence of expensive child care, and slowing down the increase in longterm care expenditure all encourage the development of informal care provided by the family. However, most of the literature on intergenerational relationships has focused on the majority groups across Europe in terms of individuals' ethnic background, or has not examined the population according to their migration history (exceptions are, for example, on intergenerational support: Bordone and de Valk 2016; on intergenerational co-residence: de Valk and Bordone in press). By investigating the similarities and differences in the use of (grandparental) child care across ethnic groups, this paper provides a more nuanced understanding of intergenerational support and contributes to shedding light on the increasing diversity of the European population.

The paper draws on previous evidence on grandparental child care to investigate the role played by individuals' ethnic origin in using any type of child care and, among those who use child care, their use of grandparental child care. We used data from Understanding Society on parent-child dyads where parents are aged 18-60 years old, were interviewed at least once over five waves and are responsible for at least one child below 15 years old. The findings provide comparative evidence of the use of grandparental child care across five ethnic groups as compared to White British and Other White respondents in the UK. The results indicate 
Table 5. Odds ratios of the logistic analyses on using child care; among those using child care, using grandparental child care; and among those using child care, only using grandparental child care, accounting for partner's ethnicity

\begin{tabular}{|c|c|c|c|}
\hline & Child care use & $\begin{array}{l}\text { Grandparental } \\
\text { child care }\end{array}$ & $\begin{array}{l}\text { Only grandparental } \\
\text { child care }\end{array}$ \\
\hline & \multicolumn{3}{|c|}{ Odds ratios (clustered standard errors) } \\
\hline \multicolumn{4}{|l|}{ Ethnicity (Ref. White British): } \\
\hline Other White & $0.844^{\star}(0.060)$ & $0.792^{\star}(0.093)$ & $0.953(0.131)$ \\
\hline Indian & $0.519^{\star \star \star}(0.043)$ & $0.983(0.143)$ & $1.428^{\star}(0.231)$ \\
\hline Pakistani & $0.470^{\star \star \star}(0.046)$ & $0.934(0.174)$ & $1.094(0.233)$ \\
\hline Bangladeshi & $0.227^{\star \star \star}(0.032)$ & $1.140(0.358)$ & $1.133(0.432)$ \\
\hline Caribbean & $1.295^{\star \star}(0.120)$ & $0.428^{\star \star \star}(0.063)$ & $0.429^{\star \star \star}(0.088)$ \\
\hline African & $0.800^{\star \star}(0.060)$ & $0.372^{\star * \star}(0.071)$ & $0.451^{\star \star \star}(0.109)$ \\
\hline Other & $0.823^{\star \star}(0.050)$ & $0.912(0.098)$ & $1.207(0.144)$ \\
\hline Working mother (Ref. Not) & $4.915^{\star \star \star}(0.162)$ & $1.317^{\star \star \star}(0.071)$ & $1.359^{\star \star \star}(0.086)$ \\
\hline \multicolumn{4}{|l|}{$\begin{array}{l}\text { Partner's ethnicity (Ref. Living } \\
\text { alone): }\end{array}$} \\
\hline With White British partner & $0.990(0.042)$ & $0.957(0.060)$ & $0.957(0.068)$ \\
\hline With Other Ethnic group partner & $0.738^{\star \star \star}(0.045)$ & $0.626^{\star \star \star}(0.068)$ & $0.636^{\star \star \star}(0.080)$ \\
\hline With partner, ethnicity not known & $0.883^{\star \star}(0.036)$ & $0.964(0.058)$ & $1.038(0.072)$ \\
\hline High education (Ref. Low) & $1.722^{\star \star \star}(0.064)$ & $0.900^{*}(0.046)$ & $0.686^{\star \star \star}(0.041)$ \\
\hline \multicolumn{4}{|l|}{$\begin{array}{l}\text { Household income (Ref. Low, 1st } \\
\text { tertile): }\end{array}$} \\
\hline Middle (2nd tertile) & $1.198^{\star \star \star}(0.043)$ & $1.116^{*}(0.060)$ & $1.100(0.066)$ \\
\hline High (3rd tertile) & $1.928^{\star \star \star}(0.071)$ & $1.061(0.058)$ & $0.903(0.057)$ \\
\hline Child age & $0.872^{\star \star \star}(0.002)$ & $1.012^{\star \star}(0.004)$ & $1.055^{\star \star \star}(0.005)$ \\
\hline \multicolumn{4}{|l|}{ Number of siblings (Ref. 0): } \\
\hline 1 & $1.668^{\star \star \star}(0.044)$ & $0.745^{\star \star *}(0.029)$ & $1.022(0.045)$ \\
\hline $2+$ & $1.241^{\star \star \star}(0.048)$ & $0.470^{\star \star \star}(0.028)$ & $0.809^{\star \star}(0.054)$ \\
\hline \multicolumn{4}{|l|}{$\begin{array}{l}\text { Proximity to grandparents } \\
\text { (Ref. }<30 \text { minutes): }\end{array}$} \\
\hline 30 minutes to 1 hour & & $0.329^{\star \star \star}(0.025)$ & $0.301^{\star \star *}(0.032)$ \\
\hline $1-2$ hours & & $0.224^{\star \star \star}(0.021)$ & $0.183^{\star \star \star}(0.025)$ \\
\hline$>2$ hours & & $0.117^{\star \star \star}(0.009)$ & $0.157^{\star \star \star}(0.016)$ \\
\hline No grandparents/missing & & $0.478^{\star \star \star}(0.033)$ & $0.608^{\star \star \star}(0.048)$ \\
\hline $\mathrm{N}$ & 68,888 & 25,145 & 25,145 \\
\hline
\end{tabular}

Notes: All models also include an indicator for the wave of interview. Ref.: reference category. Source: Authors' analysis of Understanding Society (USOC) Waves 1-5 (2009-2015).

Significance levels: ${ }^{\star} p<0.05,{ }^{\star \star} p<0.01,{ }^{\star \star \star} p<0.001$. 
Table 6. Odds ratios of the logistic analyses on using child care; among those using child care, using grandparental child care; and among those using child care, only using grandparental child care, accounting for whether at least one parent has long-standing illness or impairment

\begin{tabular}{|c|c|c|c|}
\hline & Child care use & $\begin{array}{l}\text { Grandparental } \\
\text { child care }\end{array}$ & $\begin{array}{l}\text { Only grandparental } \\
\text { child care }\end{array}$ \\
\hline & \multicolumn{3}{|c|}{ Odds ratios (clustered standard errors) } \\
\hline \multicolumn{4}{|l|}{ Ethnicity (Ref. White British): } \\
\hline Other White & $0.731^{\star \star \star}(0.052)$ & $0.732^{\star \star}(0.089)$ & $0.892(0.126)$ \\
\hline Indian & $0.464^{\star \star \star}(0.038)$ & $0.745^{\star}(0.104)$ & $1.080(0.169)$ \\
\hline Pakistani & $0.404^{\star \star \star}(0.040)$ & $0.750(0.145)$ & $0.975(0.215)$ \\
\hline Bangladeshi & $0.182^{\star \star \star}(0.027)$ & $0.895(0.283)$ & $0.853(0.328)$ \\
\hline Caribbean & $1.198 \dagger(0.114)$ & $0.406^{\star \star \star}(0.061)$ & $0.394^{\star \star \star}(0.083)$ \\
\hline African & $0.730^{\star \star \star}(0.056)$ & $0.339^{\star \star \star}(0.066)$ & $0.417^{\star \star \star}(0.102)$ \\
\hline Other & $0.759^{\star \star \star}(0.046)$ & $0.812 \dagger(0.088)$ & $1.097(0.134)$ \\
\hline Missing & $0.917^{\star}(0.032)$ & $1.289^{\star \star \star}(0.066)$ & $1.183^{\star \star}(0.068)$ \\
\hline Working mother (Ref. Not) & $4.911^{\star \star \star}(0.168)$ & $1.330^{\star \star \star}(0.074)$ & $1.318^{\star \star \star}(0.086)$ \\
\hline With partner (Ref. Living alone) & $0.892^{\star \star}(0.033)$ & $0.924(0.051)$ & $0.963(0.061)$ \\
\hline High education (Ref. Low) & $1.718^{\star \star \star}(0.064)$ & $0.911 \dagger(0.047)$ & $0.700^{\star \star \star}(0.042)$ \\
\hline \multicolumn{4}{|l|}{$\begin{array}{l}\text { Household income (Ref. Low, 1st } \\
\text { tertile): }\end{array}$} \\
\hline Middle (2nd tertile) & $1.216^{\star \star \star}(0.045)$ & $1.124^{\star}(0.062)$ & $1.101(0.068)$ \\
\hline High (3rd tertile) & $2.022^{\star \star \star}(0.078)$ & $1.066(0.060)$ & $0.897 \dagger(0.059)$ \\
\hline Long-standing illness & $1.054(0.035)$ & $0.997(0.047)$ & $0.980(0.053)$ \\
\hline Child age & $0.872^{\star \star \star}(0.002)$ & $1.012^{\star \star}(0.004)$ & $1.054^{\star \star \star}(0.005)$ \\
\hline \multicolumn{4}{|l|}{ Number of siblings (Ref. 0): } \\
\hline 1 & $1.640^{\star \star \star}(0.045)$ & $0.735^{\star \star \star}(0.029)$ & $1.022(0.046)$ \\
\hline $2+$ & $1.232^{\star \star \star}(0.049)$ & $0.460^{\star \star \star}(0.028)$ & $0.809^{\star \star}(0.056)$ \\
\hline \multicolumn{4}{|l|}{$\begin{array}{l}\text { Proximity to grandparents } \\
\text { (Ref. }<30 \text { minutes): }\end{array}$} \\
\hline 30 minutes to 1 hour & & $0.308^{\star \star \star}(0.024)$ & $0.269^{\star \star \star}(0.030)$ \\
\hline $1-2$ hours & & $0.221^{\star \star \star}(0.022)$ & $0.191^{\star \star \star}(0.028)$ \\
\hline$>2$ hours & & $0.112^{\star \star \star}(0.009)$ & $0.143^{\star \star \star}(0.016)$ \\
\hline No grandparents/missing & & $0.502^{\star \star \star}(0.036)$ & $0.654^{\star \star \star}(0.054)$ \\
\hline N & 63,556 & 23,306 & 23,306 \\
\hline
\end{tabular}

Notes: All models also include an indicator for the wave of interview. Ref.: reference category. Source: Authors' analysis of Understanding Society (USOC) Waves 1-5 (2009-2015).

Significance levels: $\dagger p<0.1,{ }^{\star} p<0.05,{ }^{\star \star} p<0.01,{ }^{\star \star \star} p<0.001$. 
significant ethnic differentials in the use of child care provided by grandparents, with all other ethnic groups reporting lower likelihood of using grandparental child care than White British individuals, after controlling for socio-economic and demographic variables.

This may at least in part be explained by ethnic differentials in areas adjacent to child care, such as economic activity patterns among working-age individuals (middle generation) which may affect the demand for the grandparents' help with child care. For example, working-age women from Indian, Pakistani and Bangladeshi communities are significantly less likely to be in paid work compared to White British women, which can directly affect the former groups' availability to care for their own children. In addition, the historical characteristics of migration among different ethnic groups may also contribute to the differentials shown in the paper, e.g. individuals from Caribbean communities continue to be more likely than other BME groups to work in the public sector, which may partly explain their greater likelihood of using child care. We partly controlled for this by including an indicator of the mother's economic activity status, however, future studies could extend this by investigating the role of the type of job (e.g. part-time/full-time; selfemployed/employee; private/public sector) of both parents. Furthermore, there might be differences in the health status of the grandparents across ethnic groups.

Unfortunately, Understanding Society does not provide information on the health status of all grandparents alive for each child and we acknowledge this as a limitation of our study. Indeed, an average poorer health status of grandparents in some BME as compared to others might be behind the lower use of grandparental child care among parents in those ethnic groups. According to Evandrou et al. (2016), BME elders of South Asian origin show a 'health disadvantage', highlighting the complexity of inequalities among different ethnic groups in the UK. A further limitation relates to the limited sample size of the five BME and Other White groups which did not allow us to consider interaction effects, e.g. between ethnic origin and migration background. We should also note that differences between the five BME groups are difficult to interpret due to the different sample sizes and composition. Notwithstanding the difficulty of identifying differences between ethnic groups, we observe an important BME effect in comparison to the White British population which could point to inequalities beyond health inequalities, e.g. in terms of their access to social services or to market services. These aspects should be further investigated in future research and suggest the need to collect more data that are representative of sub-group populations. In addition, the multivariate models used reflect the conceptual framework shown in Figure 1. However, we acknowledge that some of the associations hypothesised in the framework and found in the results may hide a two-way causal direction. For example, proximity to the grandparents may incentivise grandparental child care, but also grandparental child care may be the reason for geographical proximity.

Yet, BME groups in this study show clear differences in the use of (grandparental) child care and, in this respect, our results point to the role of cultural norms on raising children and child care that seem to permeate family life in different ethnic cultures (e.g. Kagitçibasi, 2005; Bordone and de Valk, 2016). Future studies accounting for norms in the analyses could clarify the extent of parents' orientation towards the collective or individual and indicate the willingness of grandparents to 
provide support to their children in the form of child care. As changes over time at society level (e.g. in terms of policies, services and the job market) might shape changes in child care use across ethnic groups differently, future analyses expanding this work might also consider exploring the longitudinal dimension of macromicro interactions.

The findings in this paper, therefore, have critical policy implications also, not least as a result of the socio-economic differentials existing between members of different BME communities in conjunction with the cost of child care from the formal private sector in the UK. One-parent families, which are more common among African and Caribbean communities, are more likely to require formal support in terms of child care, however, they are also less likely to be able to afford such support unless it is subsidised. On the other hand, two-parent families may also face financial challenges in accessing formal child care if only one parent is in paid work, and this is more likely to happen in Pakistani and Bangladeshi families, while higher educational qualifications do not necessarily lead to better employment opportunities and the ability to afford private child care. Such findings paint a complex picture in terms of the role of social policy, which is more relevant in enhancing opportunities for accessing child care, through a combination of employment opportunities and subsidised costs for child care, than in regulating complex family relationships affecting grandparental child care provision, which are permeated by cultural norms and practices.

Financial support. This work was supported by the ESRC Centre for Population Change (ME and AV, grant number ES/K007394/1) and the GCRF Global Ageing and Long-term Care Network (GALNet) (ME and AV, grant number ES/P006779/1).

\section{References}

Aassve A, Arpino B and Goisis A (2012) Grandparenting and mothers' labour force participation: a comparative analysis using the Generations and Gender Survey. Demographic Research S11, 53-84.

Agarin T (2014) Citizenship and collective identity in Europe. Journal of Ethnic and Migration Studies 40, 2051-2052.

Arpino B and Bordone V (2014) Does grandparenting pay off? The effect of child care on grandparents' cognitive functioning. Journal of Marriage and Family 76, 337-351.

Arpino B, Pronzato CD and Tavares LP (2014) The effect of grandparental support on mothers' labour market participation: an instrumental variable approach. European Journal of Population 30, 369-390.

Baldassar L (2007) Transnational families and aged care: the mobility of care and the migrancy of ageing. Journal of Ethnic and Migration Studies 33, 275-297.

Baydar N and Brooks-Gunn J (1998) Profiles of grandmothers who help care for their grandchildren in the United States. Family Relations 47, 385-393.

Bécares L, Nazroo J, Albor C, Chandola T and Stafford M (2012) Examining the differential association between self-rated health and area deprivation among white British and ethnic minority people in England. Social Science \& Medicine 74, 616-624.

Berthoud R (1998) The Incomes of Ethnic Minorities. Colchester, UK: Institute for Social and Economic Research. Available at https://www.iser.essex.ac.uk/files/iser_reps/pdf/001.pdf.

Bordone V (2012) Social norms and intergenerational relationships. In De Santis G (ed.), The Family, the Market or the State? Intergenerational Support Under Pressure in Ageing Societies. Dordrecht, The Netherlands: Springer, pp. 159-178.

Bordone V, Arpino B and Aassve A (2017) Patterns of grandparental child care across Europe: the role of the policy context and working mothers' need. Ageing \& Society 37, 845-873. 
Bordone V and de Valk HAG (2016) Intergenerational support among migrant families in Europe. European Journal of Ageing 13, 259-270.

Boreham R, Boldysevaite D and Killpack C (2012) UKHLS Wave 1 (Technical report). Colchester, UK: National Centre for Social Research, Institute for Social and Economic Research.

Burton J, Nandi A and Platt L (2008) Who are the UK's minority ethnic groups? Issues of identification and measurement in a longitudinal study. Institute for Social and Economic Research, Working Paper 2008-26.

Cameron AC and Trivedi PK (2010) Microeconometrics Using Stata, Rev. Edn. College Station, TX: Stata Press.

Craig G, Atkin K, Chattoo S and Flynn R (2012) Understanding 'Race' and Ethnicity: Theory, History, Policy and Practice. Bristol, UK: Policy Press.

de Valk HAG and Bordone V (in press) Co-residence of adult children with their parents: differences by migration background explored and explained. Journal of Ethnic and Migration Studies. doi:10.1080/ 1369183X.2018.1485207.

Evandrou M (2000) Social inequalities in later life: the socio-economic position of older people from ethnic minority groups in Britain. Population Trends 101, 11-18.

Evandrou M, Falkingham J, Feng Z and Vlachantoni A (2016) Ethnic inequalities in limiting health and self-reported health in later life revisited. Journal of Epidemiology and Community Health 70, 653-662.

Geurts T, Van Tilburg T, Poortman A-R and Dykstra PA (2015) Child care by grandparents: changes between 1992 and 2006. Ageing \& Society 35, 1318-1334.

Glaser K, Price D, Ribe Montserrat E, Di Gessa G and Tinker A (2010) Grandparenting in Europe. London: Grandparents Plus.

Hagestad GO (2006) Transfers between grandparents and grandchildren: the importance of taking a threegeneration perspective. Zeitschrift für Familienforschung/Journal of Family Research 18, 315-322.

Hank K and Buber I (2009) Grandparents caring for their grandchildren: findings from the 2004 Survey of Health, Ageing, and Retirement in Europe. Journal of Family Issues 30, 53-73.

Hofferth S, West J and Henke R (1994) Access to Early Childhood Programs for Children at Risk. Washington, DC: National Center for Educational Statistics.

Kagitçibasi C (2005) Autonomy and relatedness in cultural context. Implications for self and family. Journal of Cross-cultural Psychology 36, 403-422.

Kuhlthau K and Mason KO (1996) Market child care versus care by relatives. Journal of Family Issues 17, 561-578.

Liang X, Fuller B and Singer JD (2000) Ethnic differences in child care selection: the influence of family structure, parental practices, and home language. Early Childhood Research Quarterly 15, 357-384.

Lie MLS (2010) Across the oceans: childcare and grandparenting in UK Chinese and Bangladeshi households. Journal of Ethnic and Migration Studies 36, 1425-1443.

Maas W (2016) European governance of citizenship and nationality. Journal of Contemporary European Research 12, 532-551.

Office for National Statistics (2006) Focus on Older People. London: Office for National Statistics.

Pension Policy Institute (2003) The Under-pensioned: Ethnic Minorities. London: Pensions Policy Institute.

Phillipson C (2015) Placing ethnicity at the centre of studies of later life: theoretical perspectives and empirical challenges. Ageing \& Society 35, 917-934.

Piętka-Nykaza E and McGhee D (2016) Stakeholder citizenship: the complexities of Polish migrants' citizenship attachments in the context of the Scottish independence referendum. Citizenship Studies 20, 115-129.

Silverstein M, Giarrusso R and Bengtson VL (2003) Grandparents and grandchildren in family systems: a social-developmental perspective. In Bengtson VL and Lowenstein A (eds), Global Aging and Challenges to Families. New York, NY: Aldine de Gruyter, pp. 75-103.

Silverstein M and Marenco A (2001) How Americans enact the grandparent role across the family life course. Journal of Family Issues 22, 493-522.

Smith GD, Chaturvedi N, Harding S, Nazroo J and Williams R (2000) Ethnic inequalities in health: a review of UK epidemiological evidence. Critical Public Health 10, 375-408.

Timonen V and Arber S (2012) A new look at grandparenting. In Arber SL and Timonen V (eds), Contemporary Grandparenting: Changing Family Relationships in Global Contexts. Bristol, UK: The Policy Press, pp. 1-24. 
Treas J and Mazumdar S (2004) Kinkeeping and caregiving: contributions of older people in immigrant families. Journal of Comparative Family Studies 35, 105-122.

University of Essex, Institute for Social and Economic Research and NatCen Social Research (2014) Understanding Society: Waves 1-5, 2009-2014. Data collection, 7th Edn. Available at http://dx.doi.org/ 10.5255/UKDA-SN-6614-6.

Vandell DL, McCartney K, Owen MT, Booth C and Clarke-Stewart A (2003) Variations in child care by grandparents during the first three years. Journal of Marriage and Family 65, 375-381.

Vlachantoni A, Feng Z, Evandrou M and Falkingham J (2015) Ethnicity and occupational pension membership in the UK. Social Policy \& Administration 49, 801-823.

Vlachantoni A, Feng Z, Evandrou M and Falkingham J (2017) Ethnic elders and pension protection in the United Kingdom. Ageing \& Society 37, 1025-1049.

Wellard S (2011) Doing it All? Grandparents, Childcare and Employment: An Analysis of British Social Attitudes Survey Data from 1998 and 2009. London: Grandparents Plus.

Willis R, Price D and Glaser K (2013) Ethnicity as a determining factor for instrumental support in mid and later life in England and Wales. Journals of Gerontology: Psychological Sciences and Social Sciences 68B, 278-289.

Wimmer A (2008) The making and unmaking of ethnic boundaries: a multilevel process theory. American Journal of Sociology 113, 970-1022.

Cite this article: Bordone V, Evandrou M, Vlachantoni A (2020). Ethnicity and grandparental child care in the United Kingdom. Ageing \& Society 40, 713-734. https://doi.org/10.1017/S0144686X18001265 